\title{
New or previously unrecorded avian taxa from the Middle Eocene of Messel (Hessen, Germany)
}

\author{
Gerald Mayr ${ }^{1}$ \\ With 8 figures and 7 tables
}

\begin{abstract}
Three new or from this site previously unrecorded birds are described from the Middle Eocene of Messel (Hessen, Germany). Serudaptus pohli $\mathrm{n}$. gen. n. sp. is a new taxon of the Pseudasturidae and is distinguished from the other species of this family by its short and stout tarsometatarsus and the long and strong claws. An isolated foot of a gruiform bird is assigned to Idiornis cf. itardiensis (Idiornithidae) and would, if this assignment can be confirmed, demonstrate the existence of this species for a period of 23 million years. The proportions of the toes suggest that Idiornis cf. itardiensis was less cursorial than its next recent relatives, the Cariamidae. In addition thereto, an exceptionally well preserved skeleton of a sandcoleid bird (Coliiformes: Sandcoleidae) gives new information on the osteology and feathering of sandcoleid birds. The specimen resembles the genera Eoglaucidium and Anneavis but it has not been possible to assign it to one of these two genera with certainty.
\end{abstract}

Key words: Fossil birds, Eocene, Messel, Pseudasturidae, Idiornithidae, Sandcoleidae.

\section{Zusammenfassung}

Drei neue oder von dieser Fundstelle bisher nicht nachgewiesene Vögel werden aus dem Mittel-Eozän von Messel (Hessen, Deutschland) beschrieben. Serudaptus pohli n. gen. n. sp. ist ein neues Taxon der Pseudasturidae und unterscheidet sich von den anderen Arten dieser Familie durch den kurzen und gedrungenen Tarsometatarsus und die langen, kräftigen Krallen. Der isolierte Fuß eines gruiformen Vogels wird Idiornis cf. itardiensis (Idiornithidae) zugeordnet und würde, wenn sich diese Zuordnung bestätigt, die Existenz dieser Art über einen Zeitraum von 23 Millionen Jahren zeigen. Die Zehenproportionen legen nahe, dass Idiornis cf. itardiensis weniger an eine laufende Lebensweise angepasst war als seine nächsten rezenten Verwandten, die Cariamidae. Darüber hinaus zeigt ein außergewöhnlich gut erhaltenes Skelett eines Vertreters der Sandcoleidae bisher unbekannte Einzelheiten der Osteologie und Befiederung dieser Familie. Das Exemplar ähnelt den Gattungen Eoglaucidium und Anneavis, konnte jedoch keiner der beiden Gattungen mit Sicherheit zugeordnet werden.

Schlüsselwörter: Fossile Vögel, Eozän, Messel, Pseudasturidae, Idiornithidae, Sandcoleidae.

\section{Introduction}

The former oil-shale mine "Grube Messel" is located a few kilometers northeast of Darmstadt (Hessen, Germany). According to present knowledge the deposits of this site probably originated in a deep crater lake of tectonic origin during the Lower Middle Eocene (alternative hypotheses consider a basin within an extensive river system or a small section of a larger lake, see Schaal \& Ziegler, 1988). The paleoenvironment of Messel is believed to have been dominated by humid paratropical forests (a detailed description of the site can be found in Schaal \& Ziegler, 1988).
In the last decades Messel has yielded a large number of fossils in an exceptional state of preservation. In many cases not only the hard parts of the organisms are preserved but also remains of the integument and occasionally even stomach content. In terms of both the number of individuals and the number of species, birds are among the most abundant land vertebrates. So far about 50 avian species have been identified (Mayr, unpublished data) of which 22 are already described scientifically (Peters 1988, 1989, 1992, 1995, Hesse 1990, Mayr 1998a, 1998b, 1998c, Mayr \& Daniels 1998, Mayr \& Peters 1998).

\footnotetext{
${ }^{1}$ Forschungsinstitut Senckenberg, Sektion für Ornithologie, Senckenberganlage 25, D-60325 Frankfurt a.M., Germany. Received February 1999, accepted June 1999
} 
In this study three new or for this site unrecorded taxa are presented which belong to higher taxa already reported from Messel and which are not closer related to each other. Since these specimens formerly have been housed in private collections, they could not be appreciated earlier, and their description herein should be regarded as an "addendum" to previous publications (Peters 1995, Mayr 1998a, Mayr \& Peters 1998).

\section{Material and method}

The anatomical terminology follows Baumel \& Witmer (1993). The dimensions represent the maximum length of the bone along its longitudinal axis. The following abbreviations have been used to indicate collections in which specimens are deposited:

SMF - Forschungsinstitut Senckenberg. Frankfurt a.M.. Germany;

SMNK - Staatliches Museum für Naturkunde. Karlsruhe. Germany: and

WDC - The Wyoming Dinosaur Center. Thermopolis. USA.

\section{Systematic paleontology}

Order inc. sed.

\section{Pseudasturidae Mayr, 1998a}

\section{Serudaptus n. gen.}

Type species: Serudaptus pohli n. sp.

Diagnosis: Serudaptus n. gen. is characterized by its short and stout tarsometatarsus. by the presence of a crest on the medial side of the tibiotarsus opposite the crista fibularis. and by the long and strong claws.

Differential Diagnosis: Apart from the characters mentioned above, Serudapuls n. gen. differs from Pseudastur Mayr. 1998a, the only other named genus of the family, because it has a longer beak, the apex carinae of the sternum protrudes farther cranially, and because the acromion of the scapula is larger.

Etymology: The generic name is an anagram of Pseudastur, the type genus of the Pseudasturidae.

\section{Serudaptus pohli n. sp.}

Figs 1, 2

Holotype and only known specimen: WDC-C-MG 201a+b (Figs 1.2)
Diagnosis: Same as for the genus.

Differential Diagnosis: Serudaptus pohli n. gen. n. sp. is distinctly larger than Pseudastur macrocephalus Mayr, 1998a (tab. 1).

Type locality: Messel (Hessen, Germany).

Type horizon: Geiseltalium, lower Middle Eocene (see Franzen \& Haubold, 1986).

Dimensions (in mm): See tabs 1 and 2.

Etymology: The species is named in honor of Mr. Burkhard Pohl (Ferpicloz, Switzerland) who kindly made the type specimen available for study.

Preservation of the specimen: WDC-CMG 201a+b is preserved as a complete articulated skeleton on two slabs (Figs 1,2). The specimen has been prepared according to the "resin transfer method" (e.g., Toombs \& Rixon 1950, Kühne 1961). Most bones are nearly uncrushed, feather remains are only poorly preserved.

Description and comparison:

- Skull: The skull is large in comparison to the body although it is smaller in its relative size than the skull of Pseudastur (which distinctly exceeds the ulna in length). The fossae temporales appear to have been shallow and the processus postorbitales are distinct, but short. Processus supraorbitales, which are very large in Pseudastur, cannot be discerned, but might have been lost either before the skeleton was embedded in the sediment or during its preparation. The beak is nearly half as long as the entire skull and thus is in its relative length longer than the beak of Pseudastur, which measures only slightly more than $1 / 3$ of the length of the skull. The beak appears to have been robust with a fairly straight culmen, and as in Pseudastur the nostril is ovalshaped and reaches $1 / 3$ of the length of the beak. The rostrum maxillae is long and measures more than half the length of the beak. The mandible exhibits a small processus retroarticularis: the rami mandibulae are quite deep at the level of the angulus mandibulae, but become more slender towards the tip of the mandible.

- Vertebrae: The cervical vertebrae are similar to those of Pseudastur, too, and bear a distinct crista transverso-obliqua. Due to preservation it cannot be determined if the thoracic vertebrae of Serudaptus are pleurocoelous like those of Pseudastur.

- Coracoid: The coracoid resembles that of Pseudastur although it cannot be discerned if 
a foramen nervi supracoracoidei was present. The extremitas omalis is small, the processus acrocoracoideus short. The angulus medialis is pointed and reaches far medially; the processus lateralis of the sternal end is rather short.

- Furcula: The furcula is widely U-shaped as in "Primobucco" olsoni. Both the scapus claviculae and the extremitas omalis are slender.

- Scapula: As preserved, the scapula has an odd shape. It is short, the shaft is narrow and straight, and its distal end is blunt. The acromion is rather large and stout, whereas it is quite small in Pseudastur macrocephalus.

- Sternum: The margo caudalis of the sternum bears four incisions and, as far as it is comparable, resembles that of strigiform birds in the depth of the incisions and the conformation of the trabeculae. The trabecula mediana is of triangular shape. The carina sterni is rather low and similar to that of Athene noctua (Strigiformes), and the apex carinae reaches far cranially as in "Primobucco" olsoni.

- Humerus: The humerus is slender with a small proximal end and a sigmoidally bowed

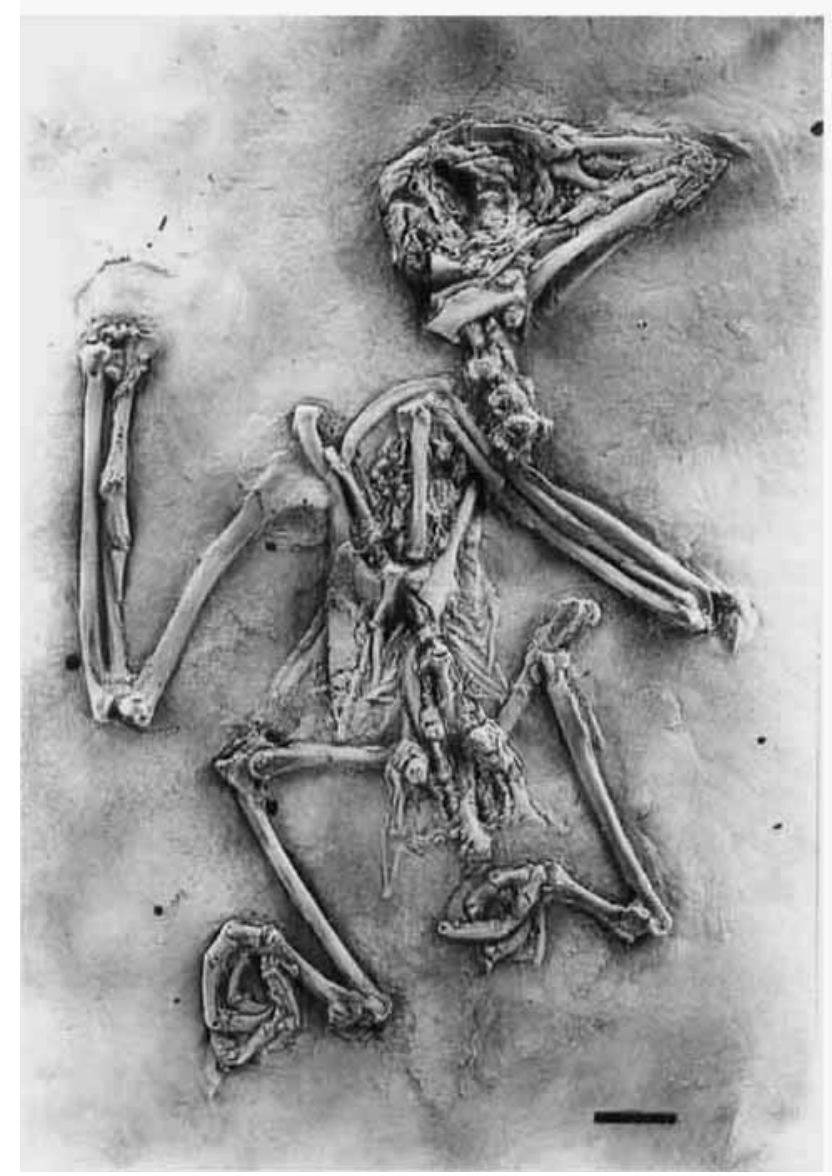

Fig. 1. Serudaptus pohli n. gen. n. sp. (holotype WDC-C-MG 201a). Coated with ammonium chloride; scale bar represents $10 \mathrm{~mm}$ shaft. Like the other elements of the wing, it closely resembles the corresponding bone of Pseudastur macrocephalus (see description in Mayr 1998a).

- Ulna: Apart from its larger size, the ulna does not differ from that of Pseudastur macrocephalus. As in the latter, the depressio radialis is very distinct (Fig. 3A, B).

- Carpometacarpus: The carpometacarpus also corresponds well with that of Pseudastur macrocephalus. A processus intermetacarpalis is absent, but the os metacarpale majus bears a small roughness at the attachment site of the tendon of the musculus extensor carpi ulnaris (musculus flexor metacarpi ulnaris of Stegmann 1978).

- Pelvis: The small pelvis resembles that of Pseudastur, its cranial part is narrow. The cristae iliacae dorsales do not meet the crista dorsalis of the synsacrum.

- Tibiotarsus: The tibiotarsus is distinguished from that of Pseudastur by its larger cristae cnemiales and in that its medial side bears a crest opposite the crista fibularis. The latter

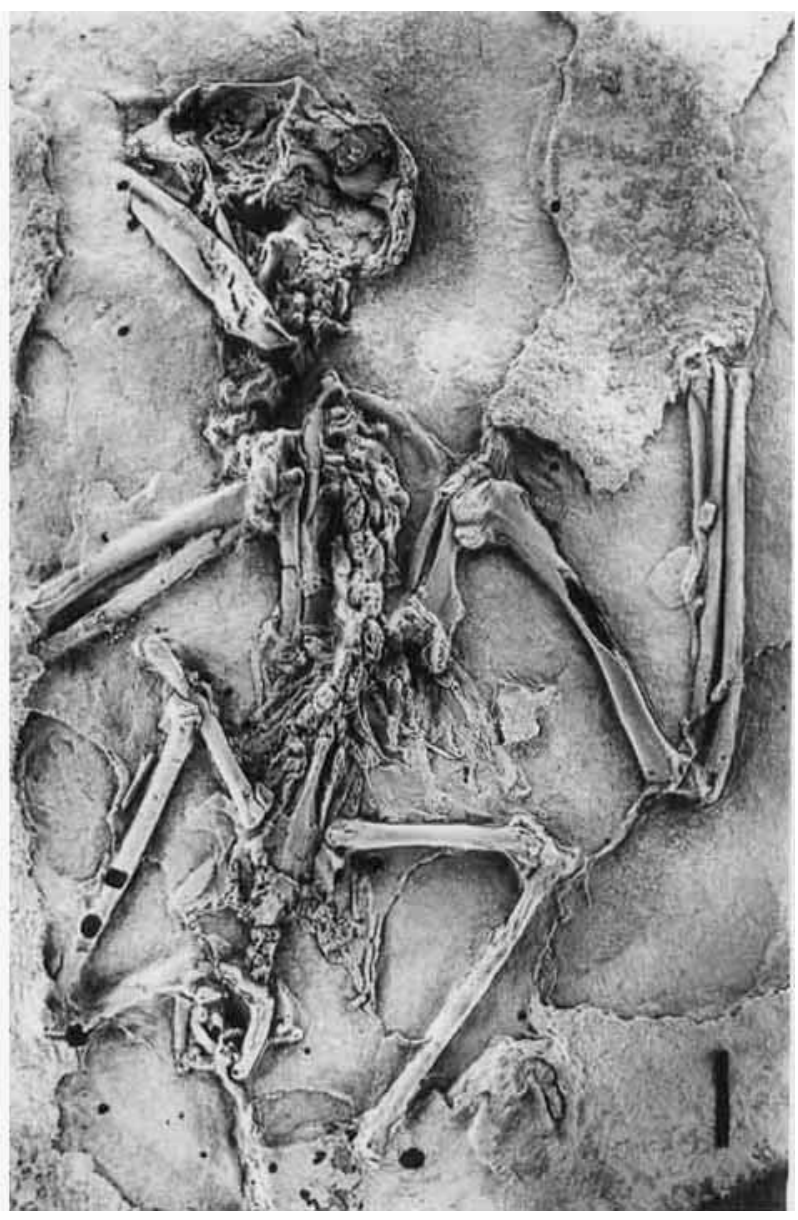

Fig. 2. Serudaptus pohli n. gen. n. sp. (holotype WDC-C-MG 201b). Coated with ammonium chloride; scale bar represents $10 \mathrm{~mm}$ 
feature is typically found in climbing birds such as Coliiformes. Pici, or Dendrocolaptidae.

- Tarsometatarsus: The tarsometatarsus is shorter and stouter than that of Pseudastur, as in the latter the dorsal surface of its shaft is convex. The hypotarsus appears to have been complex and bears at least one open sulcus. The trochlea metatarsi II is small, the trochlea metatarsi III is short. medio-laterally wide as in Pseudastur, and reaches farther distally than the trochleae metatarsorum II and IV. The trochlea metatarsi IV is turned plantad and bears a Sehnenhalter.

- Toes: The toes exhibit the normal number of phalanges. In both feet the fourth toe is opposed to the two anterior toes and thus indicates a zygodactyl foot. As in other members of the Pseudasturidae, the third toe is much stronger than the other toes. The proximal phalanges of the anterior toes are shorter than in Pseudastur: the distal (fourth) phalanx of the fourth toe is more than twice as long as the three proximal phalanges. The claws. especially that of the third toe. are much longer than those of Pseudastur and lack a sulcus neurovascularis (which is present in Pseudastur, Fig. 3C, D). Apart from being more slender, they resemble the claw of an unnamed species of the Quercypsittidae Mourer-Chau-
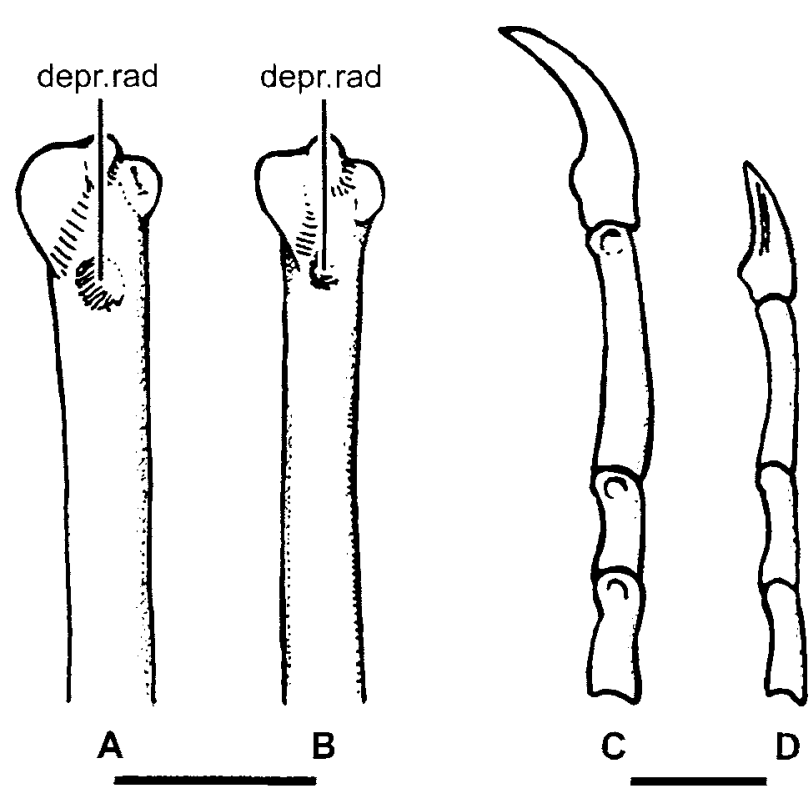

Fig. 3. Comparison of the right ulna of A. Serudaptus pohlt n. gen. n. sp. with that of B. Pseudastur macrocephalus May'r. 1998a (type specimen). Comparison of the third toc of C. Serudaptus pohli n. gen. n. sp. with that of D. Pseudastur macrocephalus Mayr. 1998 a (type specimen). Depr.rad.. depressio radialis: scale bar represents $5 \mathrm{~mm}$ viré. 1992 (Psittaciformes inc. sed.) from the Lower Eocene London Clay which is figured in Mayr \& Daniels (1998: fig. 6C). The hallux is fairly long. its claw shorter than that of the anterior toes (e.g., the claw of the third toe is nearly twice as long).

- Feathers: Feather remains are only poorly preserved, remiges and rectrices are not preserved in their entire length. The skull bears a crest of $22 \mathrm{~mm}$ length.

Discussion: One of the most characteristic features of Serudaptus pohli n. gen. n. sp. is that it exhibits a zygodactyl foot (i.e. the fourth toe is directed backwards) with the trochlea metatarsi IV of the tarsometatarsus being turned plantad and bearing a well developed Sehnenhalter. This character combination only occurs among recent Cuculiformes (cuckoos), Psittaciformes (parrots), and Piciformes (woodpeckers and allies), and among the extinct Sandcoleidae (see below) and Pseudasturidae. S. pohli very closely resembles Pseudastur, the type genus of the Pseudasturidae. in its overall osteology and further exhibits the following characters which Mayr (1998a) listed in the diagnosis of the Pseudasturidae: (1) mandible with small processus retroarticularis; (2) furcula with narrow extremitas omalis; (3) humerus slender with small proximal end and sigmoidally bowed shaft; (4) ulna distinctly longer than humerus and (5) with extremely marked depressio radialis; (6) tarsometatarsus very short; (7) third toe very strong. At least characters (4), (5), (6), and (7) most likely are derived within neognathous birds (since they are absent in paleognathous and primitive Mesozoic birds).

The Pseudasturidae Mayr, 1998a are an enigmatic group of small, zygodactyl birds which are known from the Lower Eocene of North America and England ("Primobucco" olsoni Feduccia \& Martin, 1976) and from the Middle Eocene of Messel (Pseudastur macrocephalus Mayr, 1998a and two other unnamed species, see Mayr 1998a). "Primobucco" olsoni has previously been classified in the polyphyletic family Primobucconidae Feduccia \& Martin, 1976 (see Houde \& Olson 1989, Mayr 1998a).

As already mentioned above, Serudaptus pohli is larger than either "Primobucco" olsoni or Pseudastur macrocephalus and is clearly distinguished from these two species by its relatively shorter tarsometatarsus and by the long, almost raptor-like claws. The presence of a distinct crest on the medial side of the tibiotarsus opposite to the crista fibularis is typical for climbing birds 
Table 1

Serudaptus pohli $n$. gen. n. sp. Length of the limb bones in comparison with other pseudasturid birds from Messel (lcft/right. in $\mathrm{mm}$ ).

\begin{tabular}{|c|c|c|c|c|c|c|}
\hline & humerus & ulna & $\begin{array}{l}\text { carpometa- } \\
\text { carpus }\end{array}$ & femur & tibiotarsus & $\begin{array}{l}\text { tarsometa- } \\
\text { tarsus }\end{array}$ \\
\hline $\begin{array}{l}\text { Serudaptus pohli: } \\
\text { (WDC-C-MG 201) }\end{array}$ & $/ 38.4$ & $\sim 45.3 / 46.5$ & $19.1 / 19.4$ & $\sim 23.5 / \sim 23.4$ & $38.2 / 37.4$ & $15.7 / 16.1$ \\
\hline $\begin{array}{l}\text { Preudastur macrocephalus: } \\
\text { (WDC-C-MG 94) }\end{array}$ & $1 \sim 29.5$ & $\sim 34.7 / 34.7$ & $/ 14.9$ & $\sim 19.2 / \sim 19.2$ & $30.5 / 30.6$ & $15.5 / 15.5$ \\
\hline $\begin{array}{l}\text { Pscudasturidae indet:: } \\
\text { (SMF-ME 1283) }\end{array}$ & $\sim 33.5 / \sim 34.5$ & $\sim 39.41$ & $\sim 17.2 /$ & & $/ \sim 31$ & $1 \sim 14.5$ \\
\hline
\end{tabular}

Table 2

Serudaptus pohli $\mathrm{n}$. gen. n. sp. Length of the pedal phalanges, in $\mathrm{mm}$.

\begin{tabular}{lllllllllllllll}
\hline & I1 & I2 & II1 & II2 & II3 & III1 & III2 & III3 & III4 & IV1 & IV2 & IV3 & IV4 & IV5 \\
\hline WDC-C-MG 201 & 8.0 & 4.1 & 3.2 & 6.2 & 5.3 & 4.0 & 3.9 & 9.0 & 7.7 & 3.9 & 3.4 & 3.4 & 7.6 & $\sim 6.2$
\end{tabular}

Table 3

Serudaptus pohli n. gen. n. sp., length-proportions of the limb bones in comparison with other pseudasturid birds (HUM - humerus, UL - ulna, CMC - carpometacarpus, TT - tibiotarsus, TMT - tarsometatarsus).

\begin{tabular}{lllllll}
\hline & HUM:UL & HUM:CMC & TT:TMT & UL:TMT & HUM:TMT CMC:TMT \\
\hline Serudaptus pohli n. gen. n. sp. & 0.83 & 1.98 & 2.32 & 2.88 & 2.39 & 1.20 \\
Pseudasturidae indet. (SMF-ME 1283) & 0.88 & 2.00 & 2.13 & 2.72 & 2.38 & 1.19 \\
Pseudastur macrocephalus & 0.86 & 1.95 & 1.95 & 2.26 & 1.94 & 1.00 \\
"Primobucco" olsoni" & 0.90 & 2.14 & $\sim 2.13$ & 1.97 & 1.78 & 0.83
\end{tabular}

it after measurements of a cast of the type specimen

and within recent birds occurs for example in the Coliiformes and Pici. Together with the short tarsometatarsus and the longer claws it might indicate that the genus Serudaptus was adapted to a more climbing way of life than the other genera of the Pseudasturidae.

With regard to its limb proportions (tab. 3), the new species closely resembles one of the above mentioned unnamed pseudasturid birds from Messel figured in Mayr (1998a: 207). The single known specimen of this species (SMF-ME 1283) has been classified as ?Pseudastur sp. by Mayr (1998a) but is listed as "Pseudasturidae indet." in tabs. 1 and 3 of this study. Mayr (1998c) found that, apart from the somewhat longer mandible (ca. 32.5 vs. $26 \mathrm{~mm}$ ), the skull of SMFME 1283 is difficult to distinguish from that of Messelastur gratulator Peters, 1994. This species is known from two isolated skulls bearing long processus supraorbitales and has been assigned to the Falconiformes. The new specimen described in the study confirms, however, that the assignment made by Peters (1994) is correct, since the mandible of pseudasturid birds is much more elongated than in M. gratulator (in Serudaptus pohli the mandible measures $42 \mathrm{~mm}$ ).
Specimen SMF-ME 1283 is smaller than S. pohli (tab. 1) and might be another species of the genus Serudaptus, a juvenile bird or the smaller sex of $S$. pohli, if this species was sexually dimorphic (although the six specimens of Pseudastur macrocephalus known so far do not differ significantly in their size).

Yet, contrary to $S$. pohli, SMF-ME 1283 clearly shows enlarged processus supraorbitales which closely resemble those of falconiform birds (as already mentioned above, this feature is also characteristic for Pseudastur macrocephalus). Unfortunately the skeleton of SMF-ME 1283 is too poorly preserved to allow detailed comparisons with Serudaptus pohli. Final appraisal of its exact systematic affinities will have to await further better preserved specimens, and the confirmation or refutation of the presence of elongated processus supraorbitales in S. pohli.

Although the type specimens of Serudaptus pohli and Pseudastur macrocephalus belong among the best preserved bird skeletons so far found in Messel, a convincing assignment of the Pseudasturidae to one of the existing avian "orders" (or to a cluster of recent higher taxa) has not been possible so far (see Mayr, 1998a). 


\section{"Gruiformes"}

\section{Idiornithidae (Brodkorb, 1965)}

\section{Idiornis cf. itardiensis Mourer-Chauviré, 1983}

Figs 4. 5

Referred specimen: SMF-ME $3437 a+b$.

Dimensions: see tabs 4 and 5 .

Preservation of the specimen: SMF-ME $3437 a+b$ consists of an isolated. only slightly flattened right tarsometatarsus with detached but associated toes on two slabs (Figs 4. 5). The specimen has been prepared according to the "resin transfer method" (e.g. Toombs \& Rixon 1950 , Kühne 1961).

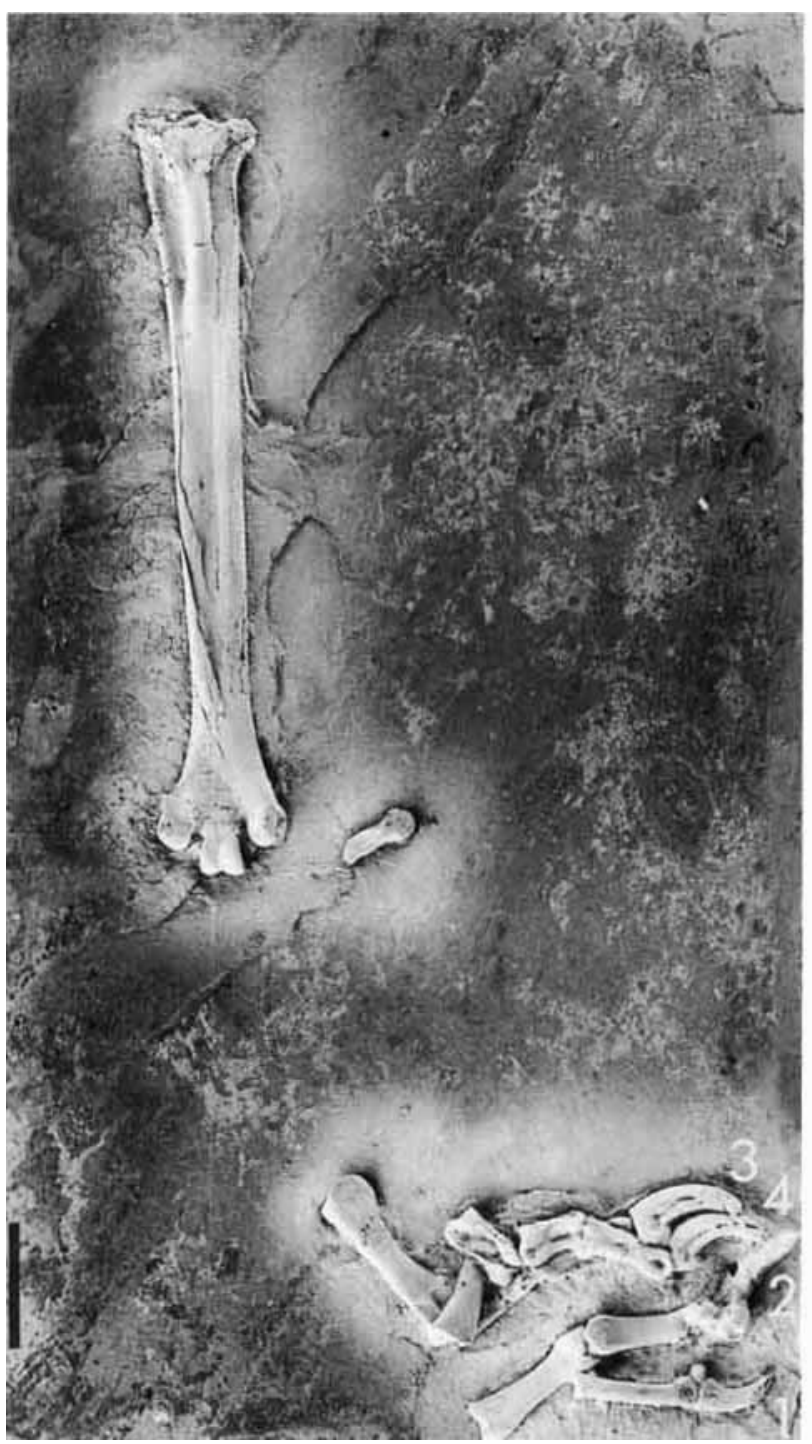

Fig. 4. Idiomis cf. itardiensis Mourer-Chauviré. 1983, right tarsometatarsus with associated toes (SMF-ME 3437a). Coated with ammonium chloride. The toes are numbered: the scale bar represents $20 \mathrm{~mm}$
Description and comparison:

- Tarsometatarsus: The tarsometatarsus (Figs 4, 5) of SMF-ME 3437 is stouter than that of most idiornithid species from the Upper Eocene of the Quercy, but corresponds well with the tarsometatarsus of Idiornis tuberculata Peters, 1995 (see below) in its proportions. The eminentia intercotylaris is large and asymmetric with the lateral flank being steeper than the medial one; the cotyla medialis reaches farther proximally than the cotyla lateralis. The hypotarsus is simple (not enclosing a bony canal) and exhibits a broad but shallow lateral groove, its edges are sharply delimited from the adjacent cotylae. The fossae parahypotarsales reach about one fifth of

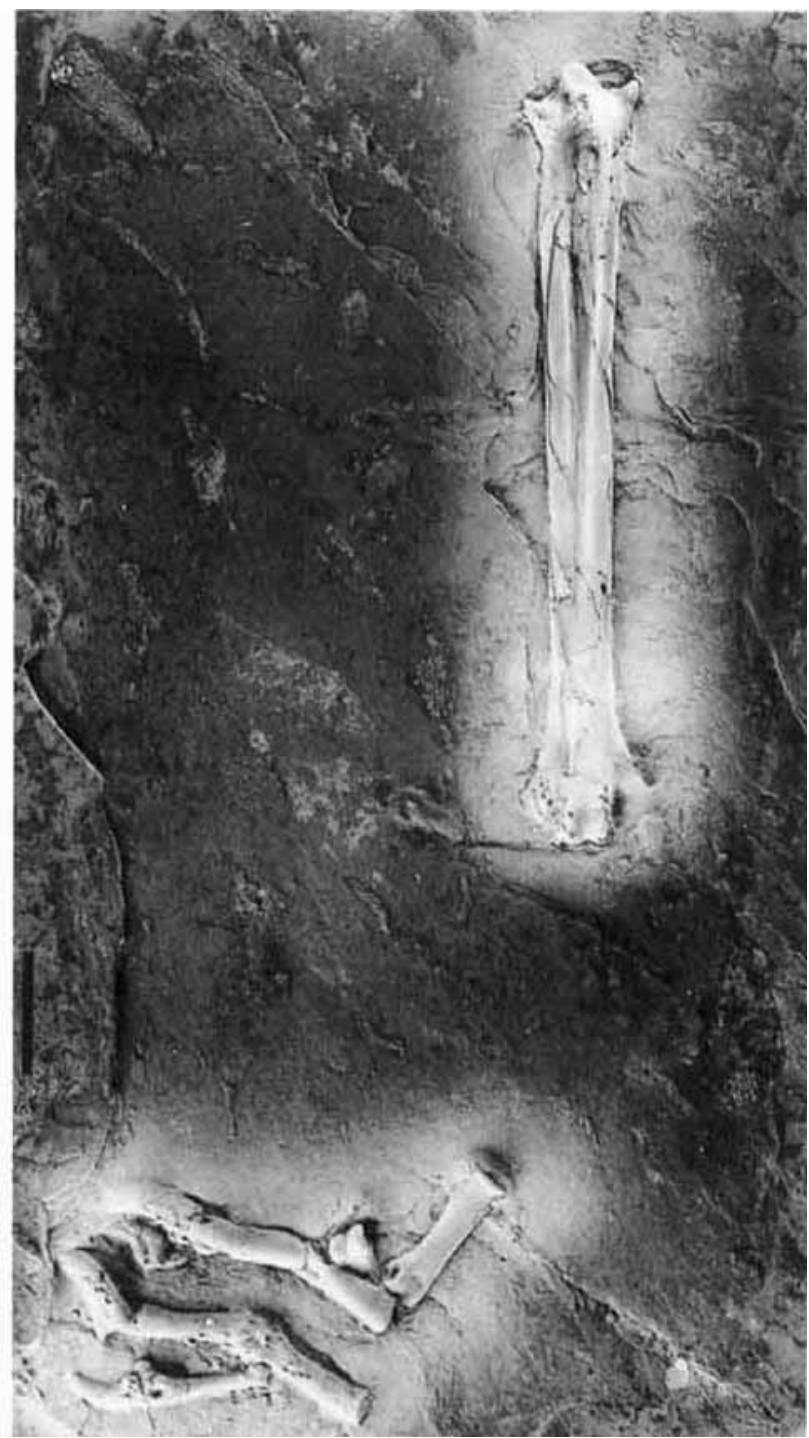

Fig. 5. Idiomis cf. itardiensis Mourer-Chauviré, 1983, right tarsometatarsus with associated toes (SMF-ME 3437b). Coated with ammonium chloride; scale bar represents $20 \mathrm{~mm}$ 
Table 4

Specimen SMF-ME 3437 (Idiornis cf. itardiensis MourerChauviré, 1983). Dimensions of the tarsometatarsus in mm, in comparison to Idiornis itardiensis and I. tuberculata.

\begin{tabular}{lcll}
\hline & length & proximal width & distal width \\
\hline SMF-ME 3437 $^{2} 122.4$ & 18.5 & 20.4 \\
I. itardiensis ${ }^{\mathrm{a}}$ & & 18.4 & 18.0 \\
I. tuberculata & 93 & 19 & 17 \\
a measurements of & & \\
$\begin{array}{l}\text { Chauvire (1983) } \\
\text { b after Peters (1995) }\end{array}$
\end{tabular}

the entire length of the tarsometatarsus. The cristae plantares are very shallow. The fossa infracotylaris dorsalis is deep. The trochleae metatarsorum II and IV have equal size and reach about half the length of the trochlea metatarsi III (in the idiornithid genus Elaphrocnemus the trochlea metatarsi II is more abbreviated).

- Toes: The toes (Fig. 4) exhibit the usual number of phalanges, in their relative length they resemble the toes of Idiornis tuberculata. The third toe is the longest and reaches about $2 / 3$ of the length of the tarsometatarsus. The second and fourth toe have roughly the same length (about half the length of the tarsometatarsus), the hallux is moderately long. The claws are large and distinctly curved, in their shape they most closely resemble the claws of some New World vultures (e.g., Sarcoramphus). A sulcus neurovascularis is present on the claws of the third and fourth toe but absent on that of the hallux. The tuberculum flexorium is small. On the plantar side of the hallux, between the proximal phalanx and the claw, a large round sesamoid bone is visible. The hallux of Idiornis tuberculata (the only other idiornithid species in which the claws are preserved) has a much shorter claw which might be due to the fact that the only known specimen of this species is that of a juvenile bird.

Discussion: The Idiornithidae are generally considered to be closely related to the recent South American seriemas (Cariamidae) (e.g.,
Mourer-Chauviré 1983). Their fossil record is restricted to European deposits and most species have been found in the Upper Eocene to Upper Oligocene fissure fillings of the Quercy, France. Although Peters (1995) reported three idiornithid species from Messel (the one presented herein not included), so far only a single species, Idiornis tuberculata Peters, 1995 has been named.

Specimen SMF-ME 3437 has been assigned to the Idiornithidae because the tarsometatarsus of this specimen exhibits the features which Cracraft (1973: 54) and Mourer-Chauviré (1983: 104) considered to be diagnostic for the tarsometatarsus of the genus Idiornis (hypotarsus without bony canals, broad and shallow groove on posterior surface of hypotarsus, edges of hypotarsus sharply delimited from adjacent cotylae, etc.). The assignment is further supported by the large and asymmetric eminentia intercotylaris and the farther proximally situated cotyla medialis of the proximal tarsometatarsus (see description).

The tarsometatarsus of SMF-ME 3437 is distinctly larger and somewhat stouter than the tarsometatarsus of most other idiornithid birds found so far, but in size and morphology corresponds very well with the tarsometatarsus of the Oligocene species Idiornis itardiensis MourerChauviré, 1983 which is known from its proximal and distal ends only (Mourer-Chauviré, 1983: pl.4). Nevertheless the assignment of SMF-ME 3437 to the species I. itardiensis should be regarded as tentative until it can be confirmed with additional skeletal elements. The Quercy I. itardiensis is known from deposits which are between 31 and 26 million years old (see Mourer-Chauviré 1983, Legendre \& Lévêque 1997) whereas the deposits of Messel have an age of about 49 million years old (see Schaal \& Ziegler 1989). Therefore the record from Messel would be 18 million years older than the specimens from the Quercy, which would suggest the existence of the species Idiornis itardiensis over 23 million years.

Table 5

Specimen SMF-ME 3437 (Idiornis cf. itardiensis Mourer-Chauviré, 1983). Length of the pedal phalanges in mm, in comparison to Idiornis tuberculata.

\begin{tabular}{llllllllllllllll}
\hline & I1 & I2 & II1 & II2 & II3 & III1 & III2 & III3 & III4 & IV1 & IV2 & IV3 & IV4 & IV5 \\
\hline SMF-ME 3437 & 19.7 & 12.6 & 22.7 & 21.6 & $\sim 19.3$ & 24.6 & 18.9 & 19.4 & $\sim 18.2$ & $\sim 16$ & 13.0 & 11.8 & 16.1 & 16.6 \\
I. tuberculata $^{\text {a }}$ & 11.6 & & 16 & 14 & 12 & 17 & 13 & 13 & 12 & 12 & 7 & 8 & 12 & 9 \\
a $^{\text {after Peters (1995) }}$ & & & & & & & & & & & & & &
\end{tabular}


Specimen SMF-ME 3437 is larger than the foot of Idiornis tuberculata from which it also differs in the longer and more curved claws. The description of Idiornis tuberculata has been based on a juvenile specimen, but because of its much smaller size and the obviously complete fusion of the metatarsal bones with tibiotarsus and tarsometatarsus, I agree with Peters (1995: 118) in considering it to be unlikely that $I$. tuberculata is a juvenile of $I$. itardiensis.

The species from Messel are the earliest records of the Idiornithidae and SMF-ME 3437 is the best preserved foot of an idiornithid bird yet known. Compared with the extant Cariamidae, the tarsometatarsus of $I$. cf. itardiensis is shorter and stouter, the os metatarsale I bears a longer processus articularis tarsometatarsalis. and the hallux is much better developed. All these differences suggest that this species was less cursorial than the extant Cariamidae. This assumption is also supported by the fact that recent Cariamidae have smaller and less strongly curved claws.

\section{Coliiformes Murie, 1872}

\section{Sandcoleidae Houde \& Olson, 1992}

Gen. et sp. indet.

Figs 6-8

Referred specimen: WDC-C-MG 148/149.

Dimensions: see tabs 6 and 7 .

Preservation of the specimen: WDC-CMG $148 / 149$ is a nearly complete skeleton on two slabs (Figs 6, 7, 9). The specimen lacks the tip of the bill and the first and second toe of the right foot. The left leg and the right foot are slightly disarticulated. Feathers are exceptionally well preserved. The specimen has been prepared according to the "resin transfer method" (e.g. Toombs \& Rixon 1950, Kühne 1961).

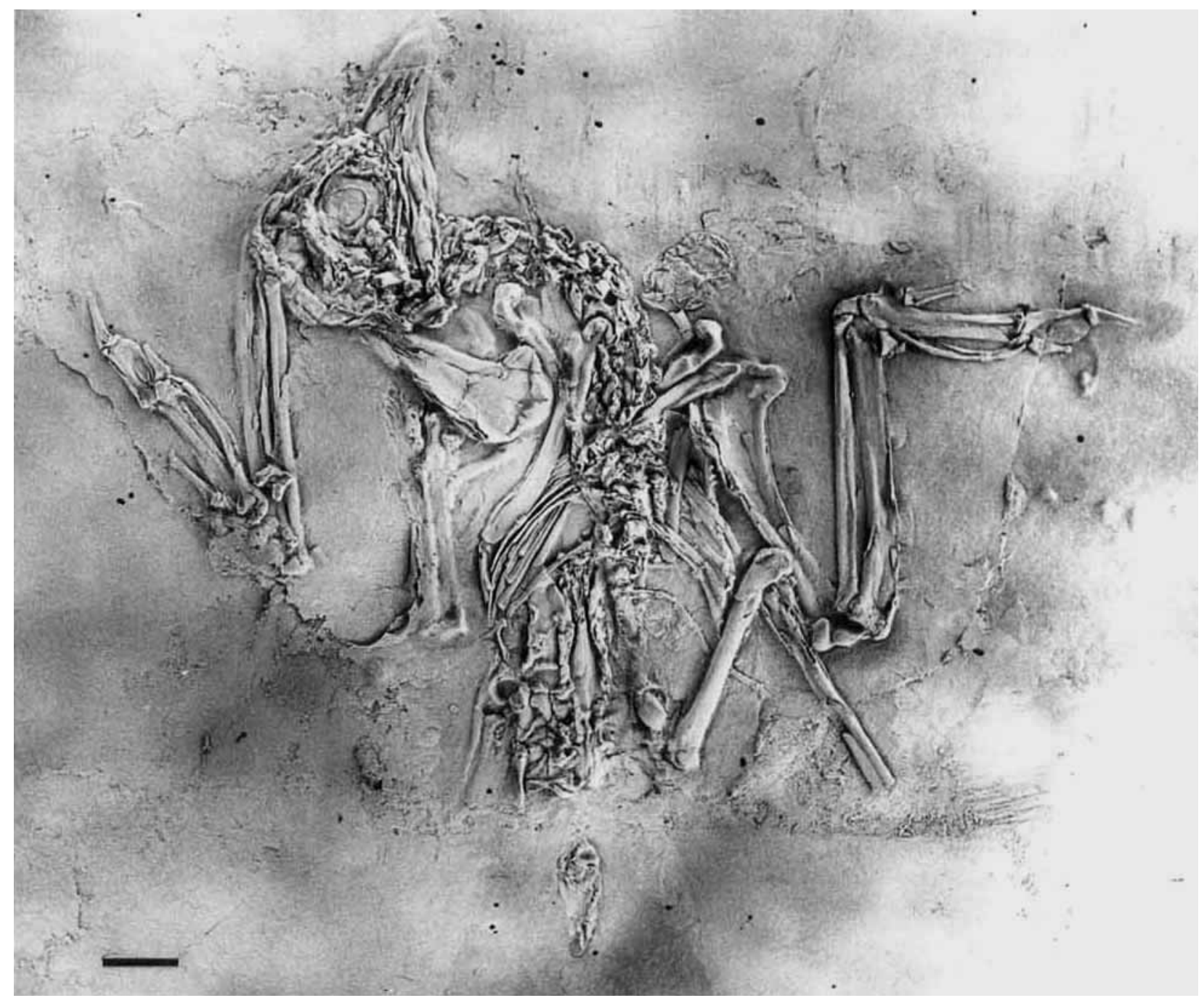

Fig. 6. Sandcoleidae, gen. et sp. indet. (WDC-C-MG 148). Coated with ammonium chloride: scale bar represents $10 \mathrm{~mm}$ 
Description and comparison:

(The specimen is very similar to the genera Eoglaucidium and Anneavis which have been described in detail by Houde \& Olson 1992, and Mayr \& Peters 1998. Therefore the following description has been restricted on those features in which it differs from the two above-mentioned genera, and on characters so far unknown for sandcoleid birds, or which are important for the phylogenetic assignment of the specimen respectively.)

- Skull: The skull appears to have been similar to that of Eoglaucidium (the skull of Anneavis is unknown). Unfortunately the distal half of the beak is missing and its shape therefore cannot be compared in detail with that of other sandcoleid taxa. The cranium also is too poorly preserved to allow the recognition of any details.

- Vertebrae: The vertebrae are only poorly preserved and allow no detailed comparisons.
Like in other sandcoleid birds the pygostyle is very large.

- Coracoid: The extremitas omalis of the coracoid most closely resembles that of Eoglaucidium and Anneavis. Like in these species (but contrary to Sandcoleus) the processus procoracoideus is very short. A small foramen nervi supracoracoidei is visible. The facies articularis scapularis is large, concave and shallow like in Eoglaucidium and Anneavis. The ventral surface of the processus acrocoracoideus bears a furrow.

- Scapula: The corpus scapulae is slightly narrower than in Sandcoleus. The distal end of the corpus scapulae is broadly rounded.

- Sternum: The sternum exhibits the characteristic sandcoleid morphology in that the trabeculae intermediae originate from the trabeculae laterales and the incisura medialis is deeper than the incisura lateralis. The transverse process of the trabeculae laterales is

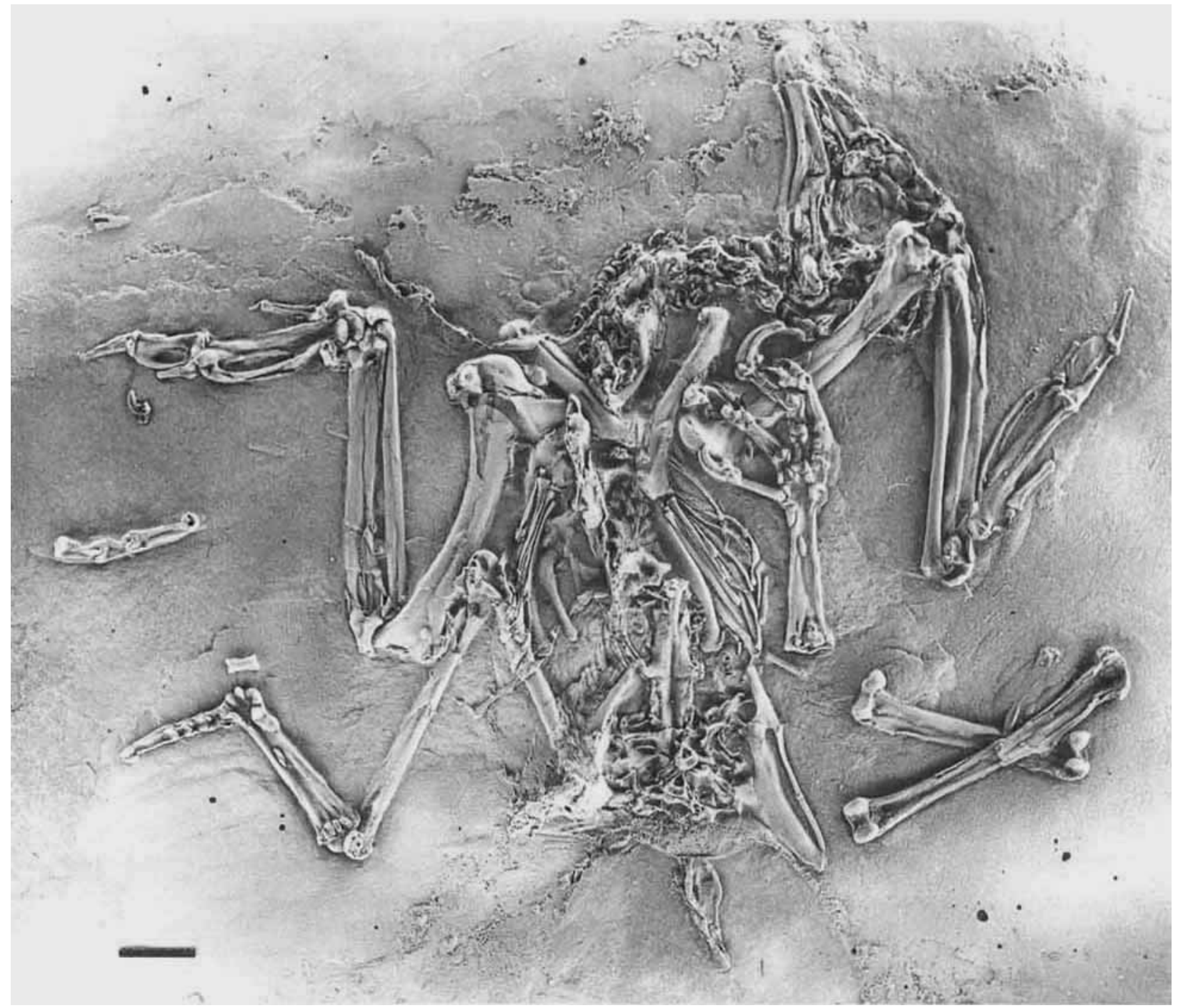

Fig. 7. Sandcoleidae, gen. et sp. indet. (WDC-C-MG 149). Coated with ammonium chloride; scale bar represents $10 \mathrm{~mm}$ 


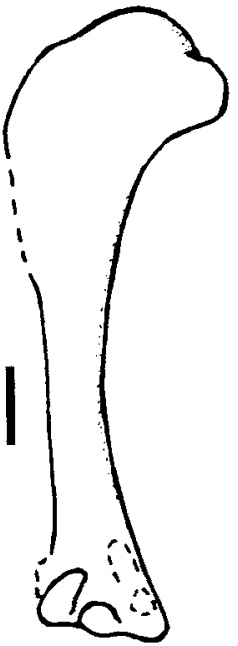

A

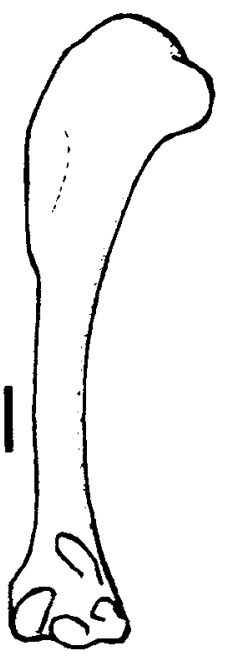

B

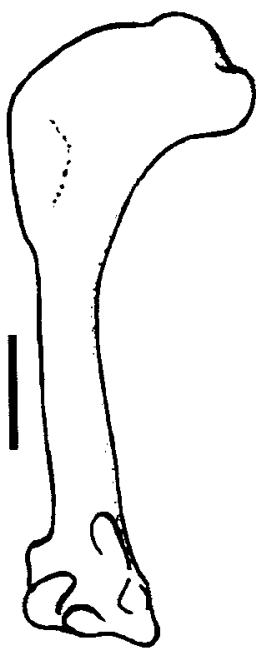

C

Fig. 8. Comparison of the right humerus of $\mathbf{A}$. Sandcoleidae. gen. et sp. indet. (WDC-C-MG 148/149) with that of B. Eoglaucidium pallas Fischer, 1987 and C. Anneavis anneae Houde \& Olson, 1992. Scale bar represents $5 \mathrm{~mm}$

smaller than in Anneavis. Like in Eoglaucidium and Sandcoleus the lateral margin of the sternum is slightly curved (in Anneavis it is straight). Details of the cranial margin are not visible.

- Ribs: Five sternal ribs can be counted and this number is in concordance with recent mousebirds.
- Humerus: Especially with regard to the medio-lateral width of its proximal end, the humerus seems to be intermediate in its proportions between the humeri of Eoglaucidium pallas and Anneavis anneae (compare Fig. 8A and $8 \mathrm{~B}, \mathrm{C}$ ). Since it is slightly flattened it might, however, appear wider than it actually was. The tuberculum ventrale is not as protruding as in Sandcoleus. The processus flexorius of the distal end appears to have been more developed than in Eoglaucidium pallas.

- Ulna: Contrary to all other sandcoleid birds except Anneavis anneae, the ulna slightly exceeds the humerus in length. The cotyla ventralis appears to have been large, the tuberculum ligamenti collateralis ventralis is very low.

- Carpometacarpus: In its shape the carpometacarpus closely resembles that of Eoglaucidium, Sandcoleus and Anneavis. The os metacarpale minus is distinctly bowed and the spatium intermetacarpale is wide. The processus pisiformis is cranio-caudally wide, its tip projects cranially.

- Other elements of the wing: The phalanx digiti alulae bears a rudimentary claw of $2 \mathrm{~mm}$ length, which is not visible in any other specimen of sandcoleid birds from Messel (as far as observable on the figure in Houde \& Olson 1992, the type specimen of $A$. anneae also

Table 6

Sandcoleidae, gen. et sp. indet. (WDC-C-MG 148/149). length of the limb bones in comparison with other sandcoleid birds (left/right, in $\mathrm{mm}$ ).

\begin{tabular}{|c|c|c|c|c|c|c|}
\hline & humerus & ulna & $\begin{array}{l}\text { carpometa- } \\
\text { carpus }\end{array}$ & femur & tibiotarsus & $\begin{array}{l}\text { tarsometa- } \\
\text { tarsus }\end{array}$ \\
\hline WDC-C-MG 148/149 & $40.8 / 41.6$ & $41.5 / 42.2$ & $22.0 / 22.0$ & $32.6 / \sim 32$ & $42.4 / \sim 42$ & $23.7 / 23.7$ \\
\hline $\begin{array}{l}\text { Eoglaucidium pallas: } \\
\text { SMNK.PAL.553 } \\
\text { SMF-ME } 8 \\
\text { SMF-ME } 1456\end{array}$ & $\begin{array}{l}46.6 / 46.6 \\
46.3 / 43.9 \\
47.9 / 44.1\end{array}$ & $\begin{array}{l}45.7 / 44.9 \\
44.3 / 43.9 \\
42.8 / 43.8\end{array}$ & $\begin{array}{c}25.0 / 24.7 \\
23.5 / 21.8 \\
-21.6 / \sim 23.6\end{array}$ & $\begin{array}{l}\sim 36.8 / \\
2 / 35.9\end{array}$ & $\begin{array}{l}49.5 / 49.6 \\
45.7 / 46.5\end{array}$ & $\begin{array}{l}26.0 / 25.8 \\
22.2 / 22.2 \\
22.3 /\end{array}$ \\
\hline $\begin{array}{l}\text { Anneavis anneae: } \\
\text { type specimen }{ }^{\text {a }}\end{array}$ & $41.7 / 40.1$ & $/ 41.5$ & $21.6 / 22.8$ & $27.7 / 33.4$ & $43.3 / 40.4$ & $23.7 / 23.5$ \\
\hline $\begin{array}{l}\text { ?Eoglaucidium sp: } \\
\text { SMF-ME } 1233\end{array}$ & $-36.9 /-37.2$ & $36.4 / \sim 35.8$ & $19.9 / \sim 20.2$ & $25.0 / 27.2$ & $35.7 / \sim 34.5$ & $22.2 / 21.1$ \\
\hline
\end{tabular}

Table 7

Sandcoleidae, gen. et sp. indet. (WDC-C-MG 148/149). length of the pedal phalanges in mm, in comparison to Eoglaucidium pallas.

\begin{tabular}{lcccccccccccccc}
\hline & I1 & I2 & II1 & II2 & II3 & III1 & III2 & III3 & III4 & IV1 & IV2 & IV3 & IV4 & IV5 \\
\hline WDC-C-MG 148/149 & 7.8 & $\sim 6.7$ & 3.9 & $\sim 8.0$ & & 6.0 & 5.3 & 9.2 & $\sim 8.5$ & $\sim 3.8$ & $\sim 3.0$ & $\sim 3.0$ & 7.7 & \\
$\begin{array}{l}\text { E. pallas: } \\
\text { SMNK-Me 553 }\end{array}$ & & 7.3 & & 6.4 & 8.8 & 5.6 & 5.3 & 11.4 & 9.7 & 3.8 & 3.8 & 3.8 & 10.5 & 9.5
\end{tabular}


seems to lack a claw on the digitus alulae, the other sandcoleid species are not known from articulated skeletons on slabs).

- Pelvis: The pelvis is wide, the anterior and posterior parts of the ilium have about equal length. The cristae iliacae dorsales do not meet the crista dorsalis of the synsacrum. The alae ischii are slender, the foramen obturatum is not closed caudally.

- Femur: The femur is straight and resembles that of other sandcoleid birds.

- Tibiotarsus: The tibiotarsus is approximately twice as long as the tarsometatarsus. Like in other coliiform birds the cristae cnemiales are enlarged and circumscribe a concavity on the cranial side of the bone. The crista cnemialis cranialis appears to be continuous with a ridge opposite to the crista fibularis. The crista fibularis itself resembles that of Eoglaucidium and Sandcoleus (in Anneavis it is more pronounced distally). The sulcus extensorius is situated medially. The condylus medialis and the condylus lateralis have about equal size and are low, the incisura intercondylaris is wide.

- Tarsometatarsus: The tarsometatarsus is similar to that of other sandcoleid birds, too. The shaft is most narrow on the level of the fossa metatarsi I and becomes gradually wider towards its proximal end. The hypotarsus closely resembles the hypotarsus of Eoglaucidium pallas, contrary to Sandcoleus and Anneavis it exhibits two open sulci. The crista lateralis hypotarsi is broad, the crista medialis and the crista intermedia are narrow. The fossa metatarsi I is situated on the medial side of the shaft. Both the trochlea metatarsi II and III are less bulbous than in Anneavis and resemble the corresponding trochleae of Eobuc$c o$ and Eoglaucidium. The trochlea metatarsi III is symmetrical and deeply grooved. The trochlea metatarsi IV bears a Sehnenhalter. Like in Eoglaucidium pallas a fairly large sesamoid bone can be observed on the plantar surface of the tarsometatarsus.

- Toes: The toes correspond well with those of other sandcoleid birds in that the proximal phalanges of the three anterior toes are very short. The claws are very long, the tuberculum flexorium is distinct. The os metatarsale I, which has not been described for sandcoleid birds so far, resembles that of recent mousebirds, the processus articularis tarsometatarsalis is short and stout.

- Feathers: The feathering (Fig. 9) of WDC-CMG $148 / 149$ is exceptionally well preserved and similar to that of recent mousebirds. The wing is rather short and rounded and the longest primary measures approximately $104 \mathrm{~mm}$. The two outermost (9th and 10th?) primaries seem to be much shorter than the adjacent feathers, although this observation is somewhat uncertain since the tip of these feathers might be lacking. The greater (upper?) coverts reach approximately $1 / 3$ of the length of the primaries. The tail is very long (approximately $152 \mathrm{~mm}$ ) and rather narrow. The length of the tail feathers is graduated, as already indicated in the reconstruction of Sandcoleus copiosus given by Houde \& Olson (1992) (the two outermost rectrices measure 56 and $77 \mathrm{~mm}$ respectively). There seem to have been ten tail feathers like in recent mousebirds (WDC-C-MG 148).

Discussion: Although the order Coliiformes comprises only a single recent family, the mousebirds (Coliidae), coliiform birds were quite diversified in the Eocene. Most of the known species belong to the extinct family Sandcoleidae (Houde \& Olson 1992, Mayr \& Peters 1998) of which seven genera (eight species) have been described so far (Eoglaucidium Fischer, 1987, Sandcoleus Houde \& Olson, 1992, Anneavis Houde \& Olson, 1992, Chascacocolius Houde \& Olson, 1992, Eobucco Feduccia \& Martin, 1976, Uintornis Marsh, 1872, Botauroides Shufeldt, 1915). Among the avian material from Messel Mayr \& Peters (1998) identified several nearly complete skeletons of Eoglaucidium pallas and tentatively referred another specimen to the genus Eoglaucidium. Specimen WDC-C-MG $148 / 149$ is the third sandcoleid species from this site and one of the best preserved skeletons of the Sandcoleidae known so far.

The specimen exhibits the characteristic sandcoleid morphology (see Houde \& Olson 1992, Mayr \& Peters 1998): the trabeculae intermediae of the sternum arise from the trabeculae laterales, the cristae cnemiales and the crista patellaris of the tibiotarsus form a continuous ridge which circumscribes a groove on the cranial side of the bone, the trochlea metatarsi IV of the tarsometatarsus bears a Sehnenhalter, the proximal phalanges of the three anterior toes are greatly shortened, and the claws are very long. Among recent and fossil birds the combination of these features is only found in the Sandcoleidae.

Specimen WDC-C-MG 148/149 differs from Sandcoleus in the short processus procoracoideus (coracoid), in the broadly rounded caudal end of 
the corpus scapulae, and in the smaller tuberculum ventrale of the humerus. It differs from Eobucco and Uintornis in the symmetric trochlea metatarsi III, and from Botauroides in the shorter trochlea metatarsi II. It is also clearly distinguished from the very coly-like genus Chascacocolius in the more bowed os metacarpale minus which does not bear a tubercle on its ventral side.

Specimen WDC-C-MG $148 / 149$ is nearly exactly the same size as the type specimen of $\mathrm{An-}$ neavis anneae in which the ulna also slightly exceeds the humerus in length (tab. 6). Yet. according to Houde \& Olson (1992: fig. 15) the hypotarsus of $A$. anneae bears only one groove and two closed canals whereas the hypotarsus of the new specimen from Messel resembles that of Eoglaucidium pallas in exhibiting two grooves (although the exact conformation of the hypotarsus of $A$. anneae is only visible in isolated tarsometatarsi of referred specimens from slightly older deposits). Specimen WDC-C-MG 148/149 further differs from $A$, anneae in the smaller transverse processes of the trabeculae laterales (sternum), and in the lateral margin of the sternum being slightly curved (straight in Anneavis). The latter character has been used by Mayr \& Peters (1998: 181) to distinguish the genera Eoglaucidium and Anneavis (due to preservation. the other characters - in Eoglaucidium the crista deltopectoralis of the humerus is less pronounced and the trochlea metatarsi IV is more raised towards the anterior side of the tarsometatarsus - are not clearly visible in WDC-C-MG 148/149).

Apart from the medio-laterally wider proximal humerus, WDC-C-MG $148 / 149$ is very similar to Eoglaucidium pallas in its osteology. Table 6 shows that the new specimen is smaller than $E$. pallas and larger than the other sandcoleid species from Messel which has been tentatively referred to the genus Eoglaucidium by Mayr \& Peters (1998) (and which differs from all other sandcoleid birds including the one described herein by its relatively shorter tibiotarsus). Especially the difference in the length of the humerus between WDC-C-MG 148/149 and the specimens of E. pallas seems to be too large to be attributed to individual variation (since WDC-C-MG $148 / 149$ shows fully developed wing and tail feathers and since the metatarsal bones are completely fused with tibiotarsus and tarsometatarsus, the specimen certainly is an adult bird; there is also no indication of sexual dimorphism in size within sandcoleid birds). The new specimen is further distinguished from E. pallas by the fact that the ulna is slightly longer than the humerus whereas the ulna is shorter than the humerus in E. pallas. Sandcoleus copiosus, Chascacocolius oscitans and in most living and fossil members of the Coliidae (see Houde \& Olson 1992, Mayr \& Peters 1998).

Since no derived characters convincingly support an assignment of WDC-C-MG 148/149 to either Anneavis or Eoglaucidium, the new specimen has been classified as "gen. et sp. indet." in this study. A direct comparison with the type specimen of $A$. anneae might reveal further characters in which the latter and the skeleton from Messel agree or differ.

\section{Acknowledgments}

I am indebted to M. Keller, Frankfurt a.M., and B. Pohl, Ferpicloz. Switzerland for kindly loaning fossil specimens for study. I would further like to thank D. Unwin (Museum für Naturkunde. Berlin) and an anonymous reviewer for critical comments on the manuscript. The photographs have been taken by S. Tränkner (Forschungsinstitut Senckenberg).

\section{References}

Baumel. J. J. \& Witmer. L. M. 1993. Osteologia. In Baumel. J. J. King. A. S., Breazile, J. E., Evans, H. E. \& Vanden Berge. J. C. (eds.). Handbook of Avian Anatomy: Nomina Anatomica Avium: Publications of the Nuttall Ornithological Club 23: $45-132$.

Brodkorb. P. 1965. New taxa of fossil birds. - Quarternary Journal of the Florida Academy of Science 28(2): $197-198$.

Cracraft. J. 1973. Systematics and evolution of the Gruiformes (Class Aves). 3. Phylogeny of the Suborder Grues. Bulletin of the American Museum of Natural History 151: $1-127$.

Feduccia. A. 1996. The Origin and Evolution of Birds. 420 pp. Yale University Press. New Haven and London.

Feduccia. A. \& Martin. L. D. 1976. The Eocene zygodactyl birds of North America (Aves: Piciformes). - Smithsonian Contributions to Paleobiology 27: 101-110.

Fischer. K. 1987. Eulenreste (Eoglaucidium pallas nov. gen., nov. sp. Strigiformes, Aves) aus der mitteleozaenen Braunkohle des Geiseltals bei Halle (DDR). - Mitteilungen aus dem Zoologischen Museum in Berlin, Supplement: Annalen für Ornithologie 11: 137-142.

Franzen. J. L. \& Haubold. H. 1986. The Middle Eocene of European mammalian stratigraphy. - Modern Geology 10: $159-170$.

Hesse. A. 1990. Die Beschreibung der Messclornithidae (Aves: Gruiformes: Rhynocheti) aus dem Alttertiär Europas und Nordamerikas. - Courier Forschungsinstitut Senckenberg 128: $1-176$.

Houdc. P. \& Olson, S. 1989. Small arboreal nonpasserine birds from the Early Tertiary of Western North America. $I n$ Ouellet. H. (ed.). Acta XIX congressus internationalis ornithologici: 2030-2036; University of Ottawa Press, Ottawa. 
- 1992. A radiation of coly-like birds from the early Eocene of North America (Aves: Sandcoleiformes new order). In Campbell, K. E. (ed.). Papers in Avian Paleontology honoring Pierce Brodkorb; Natural History Museum of Los Angeles County, Science Series 36: 137-160.

Kühne, W. G. 1961. Präparation von flachen Wirbeltieren auf künstlicher Matrix. Paläontologische Zeitschrift 35: $251-252$.

Legendre, S. \& Lévêque, F. 1997. Etalonnage de l'échelle biochronologique mammalienne du Paléogène d'Europe occidentale: vers une intégration à l'échelle globale. In Aguilar, J.-P., Legendre, S. \& Michaux, J. (eds.). Actes du Congrès BiochroM'97; Ecole pratique des Hautes Etudes Sciences de la Vie et de la Terre. - Mémoires et travaux de 1'Institut de Montpellier 21: 461-473.

Marsh, O. C. 1872. Notice on some new Tertiary and PostTertiary birds. - American Journal of Science 4(3): $256-262$.

Mayr, G. 1998a. A new family of Eocene zygodactyl birds. Senckenbergiana lethaea 78(1/2): 199-209.

- 1998b. "Coraciiforme" und "piciforme" Kleinvögel aus dem Mittel-Eozän der Grube Messel (Hessen, Deutschland). - Courier Forschungsinstitut Senckenberg 205: $1-101$.

- 1998c. Ein Archaeotrogon (Aves: Archaeotrogonidae) aus dem Mittel-Eozän der Grube Messel (Hessen, Deutschland)? - Journal für Ornithologie 139(2): 121-129.

Mayr, G. \& Daniels, M. 1998. Eocene parrots from Messel (Hessen, Germany) and the London Clay of Walton-onthe-Naze (Essex, England). - Senckenbergiana lethaea 78(1/2): $157-177$.

Mayr, G. \& Peters, D. S. 1998. The mousebirds (Aves: Coliiformes) from the Middle Eocene of Grube Messel (Hessen, Germany). - Senckenbergiana lethaea 78(1/2): $179-197$.

Mourer-Chauviré, C. 1983. Les Gruiformes (Aves) des Phosphorites du Quercy (France). 1. Sous-ordre Cariamae (Cariamidae et Phorusrhacidae). Systématique et biostratigraphie. - Palaeovertebrata 13(4): 83-143.
- 1992. Une nouvelle famille de Peroquets (Aves, Psittaciformes) dans l'Eocene superieur du Quercy, France. Geobios, M.S. 14: 169-177.

Murie, J. 1872. On the genus Colizs, ist structure and systematic position. - Ibis 14: 262-280.

Peters, D. S. 1988. Die Messel-Vögel - eine Landvogelfauna. In Schaal, S. \& Ziegler, W. (eds.). Messel - Ein Schaufenster in die Geschichte der Erde und des Lebens: 135-151; Kramer, Frankfurt a.M.

- 1989. Fossil birds from the oil shale of Messel (Lower Middle Eocene, Lutetian). In Ouellet, H. (ed.). Acta XIX congressus internationalis ornithologici: 2056-2064: University of Ottawa Press, Ottawa.

- 1992. A new species of owl (Aves: Strigiformes) from the Middle Eocene Messel Oil Shale. In Campbell, K. E. (ed.). Papers in Avian Paleontology honoring Pierce Brodkorb; Natural History Museum of Los Angeles County, Science Series 36: 161-169.

- 1994. Messelastur gratulator n. gen. n. spec., ein Greifvogel aus der Grube Messel (Aves: Accipitridae). - Courier Forschungsinstitut Senckenberg 170: 3-9.

- 1995. Idiornis tuberculata n. spec., ein weiterer ungewöhnlicher Vogel aus der Grube Messel (Aves: Gruiformes: Cariamidae: Idiornithinae). In Peters, D. S. (ed.). Acta palaeornithologica; Courier Forschungsinstitut Senckenberg 181: $107-119$.

Schaal, S. \& Ziegler, W. 1988. Messel - Ein Schaufenster in die Geschichte der Erde und des Lebens. 315 pp., Kramer, Frankfurt a.M.

Shufeldt, R. W. 1915. Fossil birds in the Marsh collection of Yale University. - Transactions of the Connecticut Academy of Arts and Science 19: 1-110.

Stegmann, B. 1978. Relationships of the superorders Alectoromorphae and Charadriimorphae (Aves): a comparative study of the avian hand. - Publications of the Nuttall Ornithological Club 17: 1-119.

Toombs, H. A. \& Rixon, A. E. 1950. The use of plastics in the "Transfer Method" of preparing fossils - Museums Journal 50: 105-107. 